\title{
INFLUENCE OF HUMAN RESOURCES COMPETENCE ON EMPLOYEE WORK EFFECTIVENESS
}

\author{
${ }^{1}$ Isal anwar hasan, Samsul rizal ${ }^{2},{ }^{3}$ Nurmi \\ ${ }^{1}$ Department of management science, graduate programme, university of muslim indonesia \\ ${ }^{2}$ Department of management science, graduate programme, university of muslim indonesia \\ ${ }^{3}$ Department of management, university of muhammadiyah makassar \\ Corresponding Author : isalanwar85@gmail.com \\ DOI: 10.31364/SCIRJ/V7.i11.2019.P1119727 \\ http://dx.doi.org/10.31364/SCIRJ/v7.i11.2019.P1119727
}

\begin{abstract}
The purpose of this research is to know the influence of human resources competency consisting of knowledge, skills, and attitude towards employee work effectiveness. This research is done by quantitative methods. The techniques used in the collection of data on this research are questionnaires, interviews, library studies. This research uses 2 (two) types of data sources namely primary data and secondary data, the data analysis used in the research is a descriptive analysis and multiple regression analysis. The results of this study show that employees ' work effectiveness, simultaneously influenced by knowledge variables, skills and attitudes.
\end{abstract}

Keywords : Competence (knowledge, skills, attitudes.), employee work effectiveness

\section{INTRODUCTION}

Human Resource problems are still a highlight and focus on sticking with the advancement of Science and technology. Human resources have a leading role in each institution's activities. Although supported infrastructure as well as excessive sources of funds but without the support of reliable human Resources Agency activities will not run properly.

Human resources are key points to be considered with all the needs. Human resources are the spearhead that will determine the success of implementing agency activities. Human Resource management affects the performance of the organization with The practice of management conducted and has a fairly broad target is not limited to operational officers only, but includes managerial levels. The essence of human resource management is the management of human beings in the organization optimally to make organizational performance as expected.

The assumption that is born of human resource management is that human beings have the intellect, feelings, desires, abilities, skills, knowledge, encouragement, power and Karsa. All of this potential affects the organizational effort in achieving its objectives. However, the technology, capital, Natural resources, but if without human resources it will be difficult for the organization to achieve its objectives. However good is the goal and organizational plan, it will be wasted if the human resources element is not professionally managed.

It is increasingly obvious because the role of human resources as a factor of crisis that can determine the progress and the life of the death of a joint venture and activities, both the form of social organizations, government agencies and business entities. Low human resources lead to the decline of employees ' working effectiveness, which is indirectly determined by the competency (Wibowo,2007:87).

According to Argis in Tangkilisan (2005:139) That work effectiveness is the optimal balance or approach to achieving the objectives, capabilities, and utilization of human resources. So the concept of effectiveness rate shows at how far the 
organization carries out activities or functions so that a predetermined goal can be achieved by using optimally existing tools and resources.

In achieving these objectives, there are several things that include working effectiveness, i.e. work quantity, quality of work, and timeliness in completing the work, as well as good quality of work. So that the effectiveness of work needs to be supported by human resources that have the competence needed by the agencies so as to obtain the results effectively and efficiently. The agency is also required to know and develop factors that support the improvement in the effectiveness of officers and leaders.

According to Wibowo (2007:87), competence is a fundamental characteristic of each individual associated with the criteria referenced to superior or effective performance in a job or situation. Competency-based human resource development is done in order to provide results in accordance with the objectives and objectives of the institution with predefined performance standards.

Based on the above, the author is interested in conducting research with the title "Influence of human resources competence on the effectiveness of work

\section{RESEARCH METHODS}

This type of research is quantitative research, This study was conducted at the Office of the Financial management of Bulukumba District and research held 2019. The techniques used in the collection of data on this research are:

1. Questionnaire, disseminating a list of questions that have been given alternative answers to answer them to the elected respondents.

2. Interviews, interviews directly with respondents and related parties.

3. Library Study, namely by collecting and studying the information and data obtained by journals, literature books, magazines and inter-et related to this research.

This Research uses 2 (two) types and data sources that are: 1 (one) primary data, IE data obtained directly from the respondent selected at the site of the study. Primary data is obtained by providing questionnaires and interviews to selected respondents. 2 (two) secondary data, i.e. data obtained through library studies by studying various writings from books, journals, magazines and the Internet to support this research. The data analysis used in this research is:

a. Descriptive analysis is used to analyse the influence of human resources competence on the effectiveness of work

b. Multiple regression analyses are methods used to answer the connection between each free variable with a bound variable.

\section{THE RESULTS OF THE STUDY}

\subsection{Characteristics of respondents}

The main object of research is measuring free variables consisting of knowledge (X1), Skill (X2), and Attitude (X3). The respondent's identity disclosure is done in an effort to give an idea that in this study there were various samples. Referring to the problem of research formulated, the identity of respondents such as gender, marital status, education level, employment, class and the number of salary per month. The research was conducted against 50 respondents, all of which were employees working at the district Financial Management office of Kab. Bulukumba. Research aims to know and analyze the effect of human resources competency on employee work effectiveness

\section{1. gender}

Based on the results of research conducted at the Office of the Financial Management Department Bulukumba District. Then it can be seen in the Gender identity table as follows;

Table 1. Respondent distribution by gender

\begin{tabular}{|l|l|l|}
\hline Gender & Amount (people) & Percentage (\%) \\
\hline
\end{tabular}




\begin{tabular}{|l|c|c|}
\hline male & 27 & 54 \\
females & 23 & 46 \\
\hline Total & 50 & 100,0 \\
\hline
\end{tabular}

\section{Source: survey results, 2019}

Based on table 1. Can be described as male-gender respondents of 27 or $54 \%$ and the remainder being female as much as 23 people or $46 \%$. Thus, the total number of male respondents is more than females.

\section{Marital status}

of a person's marital Status theoreically affects the values adopted and the level of necessity. The distribution of respondents based on marital status can be seen in the following table;

Table 2. Respondents distribution based on marital Status

\begin{tabular}{|l|c|c|}
\hline \multicolumn{1}{|c|}{ Marital status } & Amount (people) & Percentage (\%) \\
\hline married & $\mathbf{3 1}$ & $\mathbf{6 2}$ \\
\hline Not married & 19 & 38 \\
\hline Total & 50 & 100,0 \\
\hline
\end{tabular}

\section{Source: survey results, 2019}

Based on table 2. Respondents can be known that as many as 31 people (62\%) Was married while respondents who had not married only 19 people (38\%). It can illustrate that employees have an emotional maturity in the office of the District Financial Management department. Bulukumba.. If the assumption is that generally married people have an emotional maturity and good wisdom it can also give a positive boost to the employee's performance.

\section{Education level}

A person's level of education can be a measure that can define the breadth of insight, ability, attitude, values and needs. For an education level officer is important because it can relate to shaking and generation and if connected with performance, then theoretics better the level of education of one better also the ability And the better the responsibilities of the work. The research results of the respondents education level are shown in the following table:

Table 3 respondents distribution based on education level

\begin{tabular}{|l|c|c|}
\hline \multicolumn{1}{|c|}{ Education level } & $\begin{array}{c}\text { amount } \\
\text { (people) }\end{array}$ & Percentage (\%) \\
\hline High School & 4 & 8 \\
Associate's degree & 19 & 38 \\
Bachelor & 22 & 44 \\
Master Degree & 5 & 10 \\
\hline Total & 50 & 100,0 \\
\hline
\end{tabular}

Source: survey results, 2019

In table 3, shows that there are no respondents at the level of education in SLTA as much as 4 people (8\%) Then a Diploma of 19 people (38\%), and in general, the respondent has a bachelor's degree (SI) in 22 people (44\%) and S2 as many as 5 people or about $10 \%$. 


\section{Employment Period}

The employment of a civil servant describes the length of a person working as a civil servant. The longer a person works more and more of his experience. The spread of respondents based on the work period is shown in the following table:

Table 4 respondents distribution by employment

\begin{tabular}{|l|c|c|}
\hline Employment Period & amount (people) & Percentage (\%) \\
\hline $1-10$ Years & 19 & 38 \\
$11-20$ Years & 17 & 20 \\
$21-30$ Years & 10 & 8 \\
$31-50$ Years & 4 & 0 \\
Above 50 Years & 0 & $\mathbf{1 0 0 , 0}$ \\
\hline Total & $\mathbf{5 0}$ & 34 \\
\hline
\end{tabular}

\section{Source: survey results, 2019}

In table 4 shows that respondents in this study, generally have a working period of between 1-10 years, i.e. as much as 19 people (38\%), 17 people (34\%) has a working period between 11-20 years, 10 people (20\%) Has a work period of 21-30 years, 4 people ( $8 \%$ ) has a working period of 31-50 years and no respondent has had a working period of over 50 years.

\section{Rank and group}

The better an employee is the better the level of salary and allowances it receives. This can be an overview of the amount of income that an employee receives each month. The distribution of respondents by rank is shown in the following table:

Table 5. Respondents distribution by rank and group

\begin{tabular}{|l|c|c|}
\hline \multicolumn{1}{|c|}{ Rank and group } & amount (people) & Percentage (\%) \\
\hline Group 1 & 19 & 38 \\
Group 2 & 21 & 20 \\
Group 3 & 10 & $\mathbf{1 0 0 , 0}$ \\
\hline
\end{tabular}

Source: survey results, 2019

Based on table 5, it is known that the respondents in this study had group 2 of 21 people (42\%), with golongan 1 of 19 people (38\%) And in Group 3 as many as 10 people (20\%).

\section{Monthly salary}

Monthly salary reflects the magnitude of the respondents ' income received monthly as a logical consequence of its work as a civil servant. The better the earning rate of a civil servant, the better the performance of the task is theoretic. Spread of respondents based on monthly salary is indicated on:

Table 6. Respondents distribution based Monthly salary 


\begin{tabular}{|l|c|c|}
\hline \multicolumn{1}{|c|}{ Salary Amount } & amount (people) & Percentage (\%) \\
\hline Under 1.000 .000 & 0 & 0 \\
Rp. 1.000.000-1.500.000 & 17 & 34 \\
Rp. 1.501.000-2.000.000 & 23 & 20 \\
Above 2.000.000 Total & 10 & $\mathbf{1 0 0}$ \\
\hline \multicolumn{2}{c|}{ T0 } \\
\hline
\end{tabular}

\section{Source: survey results, 2019}

Based on the monthly salary of respondents can be grouped into 4 (four), namely no respondent who has salary under Rp. 1 million,-monthly, which has a salary of Rp. 1.000.000-1,500,000,-as many as 17 people (34\%), who have monthly salary Rp 1.501.000-2.000.000., As much as 23 people (46\%) And there are only 10 respondents or approximately (20\%) which has a salary above Rp. 2 million,-in the table above, it appears that generally respondents have relatively low income if associated with the magnitude of life needs of this adult.

Identification of the research respondent as outlined above indicates a diversity, although it is not intended to associate it with research variables to be scientifically tested in this study, but diversity It can give an idea that in this study netted respondents with varying characteristics.

\subsection{Variable Research}

variables research variables consist of 4 (four) variables consisting of 3 (three) independent variables, including knowledge $\left(\mathrm{X}_{1}\right)$, Skill $\left(\mathrm{X}_{2}\right)$, and Attitude $\left(\mathrm{X}_{3}\right)$ as well as 1 (one) dependent variable of employee work effectiveness $(\mathrm{Y})$.

\section{Knowledge $\left(\mathbf{X}_{1}\right)$}

Knowledge levels are indispensable so that employees can perform their duties, functions and obligations, this means that employees know their position in the organization. So the level of knowledge can make the job quality better for every employee in the group, in order to achieve one goal. Data about the respondent's response to knowledge variables was obtained from 50 respondents.

Table 7. Respondents answers distribution of questions related to knowledge variables

\begin{tabular}{|c|c|c|c|}
\hline No & Distribution of answers & amount (people) & Percentage $(\%)$ \\
\hline 1 & Excellent & 12 & 24 \\
\hline 2 & Good & 22 & 44 \\
\hline 3 & Good enough & 14 & 28 \\
\hline 4 & amateurish & 2 & 4 \\
\hline 5 & Not good & 0 & 0 \\
\hline & Amount & 50 & 100 \\
\hline
\end{tabular}

\section{Source: Data Results, 2019}

Based on the results of a descriptive statistical data management on table 7 , it is generally stated that most of the respondents were $44 \%$ expressed knowledge including the category of good views from the level of knowledge owned by 
employees In completing its duties, functions and obligations as employees in carrying out every job as many as 12 people or about $24 \%$ in the category is very good. There are about $28 \%$ of respondents stating good enough or as many as 14 people.

It also shows that good knowledge must be improved as it can improve employee performance, the implementation of a quality work is based on the level of knowledge that will increase the effectiveness of Work of an employee.

\section{Skills $\left(\mathbf{X}_{2}\right)$}

The Instrument used to measure employee skill variables is a questionnaire consisting of 4 question items measured using indicators; Ability for employees to work better, ability for employees to maintain the quality of their work, accuracy in the appropriation of given tasks, The ability to use information technology in the performance of its duties, functions and obligations. These four indicators are scores using a 5-point Likert scale so that the lowest expectation score is 4 and the best expectation score is 20 with a very supportive classification, support, supportive, not supportive, and very unsupportive. Data on the respondent's response to the skill variables are obtained from 50 respondents. The research results are shown in the following table:

Table 8. The respondent's answer to questions relating to the skill variables

\begin{tabular}{|c|c|c|c|}
\hline No & Distribution of answers & amount (people) & Percentage $(\%)$ \\
\hline 1 & Excellent & 12 & 24 \\
\hline 2 & Good & 23 & 46 \\
\hline 3 & Good enough & 15 & 30 \\
\hline 4 & amateurish & 0 & 0 \\
\hline 5 & Not good & 0 & 0 \\
\hline & Amount & 50 & 100 \\
\hline
\end{tabular}

Source: survey results, 2019

Based on the results of a descriptive statistical data processing on table 8 , it can generally be stated that most or $46 \%$ of respondents expressed good, $30 \%$ stating good enough and as much as $24 \%$ stated very well. It also shows that to improve the performance of employees, employees must have the ability to use their skills to work better, the ability of employees to work in accordance with the basic planning and tasks. and functions become imperative

\section{Attitude (X3)}

Table 9. The respondent's answer to questions relating to attitude variables

\begin{tabular}{|c|c|c|c|}
\hline No & Distribution of answers & amount (people) & Percentage $(\%)$ \\
\hline 1 & Excellent & 15 & 30 \\
\hline 2 & Good & 23 & 46 \\
\hline 3 & Good enough & 12 & 24 \\
\hline 4 & amateurish & 0 & 0 \\
\hline 5 & Not good & 0 & 0 \\
\hline & Amount & 50 & 100 \\
\hline
\end{tabular}

\section{Source: survey results, 2019}

Based on the results of a descriptive statistical data processing on table 9 , it can generally be stated that most or $46 \%$ of respondents expressed good attitude towards $24 \%$ expressed good enough and as much as $30 \%$ stated very well. It also shows that to improve employee performance, employees should have a good attitude in carrying out their duties and responsibilities in the Organization in order to work better, the attitude of employees in the organization should be aligned With organizational objectives.

\section{Work effectiveness (Y)}


Instruments used to measure employee performance variables are questionnaires consisting of 5 question items, and measured using indicators; Encouragement to help fellow friends in Data on the respondent's response to the performance variables were obtained from 50 respondents. Based on this, the frequency distribution table may be created as follows. Table 10. The respondent's answer to questions relating to variable performance effectivenessthe work, encouragement to work better in themselves, a sense of pride in work, confidence in ability, and doing work sincerely and sincerely. The five indicators are score using 5 point Likert scale so that the lowest expectation score is 5 and best expectation score is 25 with very low classification, low, enough, good and very good.

Data on the respondent's response to the performance variables were obtained from 50 respondents. Based on this, the frequency distribution table may be created as follows.

Table 10. The respondent's answer to questions relating to variable performance effectiveness

\begin{tabular}{|c|c|c|c|}
\hline No & Distribution of answers & amount (people) & Percentage $(\%)$ \\
\hline 1 & Excellent & 3 & 6 \\
\hline 2 & Good & 32 & 64 \\
\hline 3 & Good enough & 15 & 30 \\
\hline 4 & amateurish & 0 & 0 \\
\hline 5 & Not good & 0 & 0 \\
\hline & Amount & 50 & 100 \\
\hline
\end{tabular}

Source: survey results, 2019

Based on the results of the descriptive statistical data management above, it is stated that $64 \%$ of respondents had good performance as much as $30 \%$ of respondents with fairly good performance, and as many as $6 \%$ have excellent performance. This can also indicate that in order to improve performance, one employee should be able to help a friend in the job, an encouragement to work better in themselves, a sense of pride in the work, confidence in Ability, and do the work sincerely and sincerely.

\subsection{Research regression analysis Results}

The research Data was prepared with the help of SPSS, 18.00. To test the research hypothesis that the human resources competency has an effect on the effectiveness of personnel work at the office of Bulukumba District Finance Management. From the analysis results obtained double regression equation as follows:

$Y=0,621+0,453 X_{1}+0,393 X_{2}+0,066 X_{3}$

From the equation of multiple regression as above, can be interpretation as follows:

1. The value of a b0 (constant) coefficient of 0.621 means if the knowledge factor (X1), Skill factor (X2), and attitude factor (X3) equals zero, then the employee effectiveness is estimated at 1.096.

2. The coefficient value of $\mathrm{b} 1=0.453 \mathrm{X} 1$ means if the knowledge variable is improved both the frequency and quality according to the employee's job field will have a positive effect on the employee's performance, in the sense of improving employee performance assuming Other constant variables.

3. Coefficient value of $\mathrm{b} 2=0.393 \mathrm{X} 2$ indicates that skills have a positive impact on employee performance, if employees are able to direct and use skills well then the employee's performance is expected to increase with the assumption Other constant variables.

4. The coefficient value of $\mathrm{B} 3=0.066 \mathrm{X} 3$ indicates that the attitude of an employee has a positive effect but not significant to the employee's performance, if the employee can provide or demonstrate a good attitude towards the organization then it is estimated Employee performance will also increase but not significant assuming other variables are constant. 
Based on the results of the regression analysis it is known that the knowledge, skills and attitudes variables show positive values, which means there is a direct link between $\mathrm{X}$ variables (independent) with a variable $\mathrm{Y}$ (dependent).

The table Anova shows the value of $\mathrm{F}($ Value $)=28.053$ with a value of $\mathrm{p}((=0.05)$ or significance level $0,000 \mathrm{~A}$ provides information about the significance of the model at a significant degree of $0.05((=5 \%)$, this means that the model is statistically significant because the value of $\mathrm{P}$ is $<(=0.05(0.000<0.05)$. Because the models are significant, the simultaneous knowledge variables (X1), Skills (X2), and Attitudes (X3) are significantly influential on employees ' working effectiveness (Y).

The results of the analysis supported the hypothesis that the knowledge, skills, and attitudes variables have a significant effect on the performance of employees at the office of Bulukumba District Financial management. The magnitude of the model's ramal power is given by the value of the coefficient of determination symbolized by $\mathrm{R} 2$ (R-Square) $=0.647$ indicating that the model has a ramal power of 0.647 or about $64.7 \%$. The variation in ups and downs of employee performance can be explained by the model or influenced by the knowledge variables, skills, and attitudes while the remaining $25.3 \%$ are influenced by other factors not included in the analytical model.

Further to see the influence of each of the variables independent of the dependent variable $(\mathrm{Y})$ can be described in detail as follows:

\section{Effect of knowledge (X1) on employee work effectiveness (Y)}

According to the test coefficient was acquired $\mathrm{T}$-calculate $\mathrm{X} 1$ of 5.327 while the significance value indicated by the value $\mathrm{p}<(=0.00(0.000<0.05)$ which means a partial of the knowledge variable $(\mathrm{X} 1)$ is influential and significant to the employee's performance (Y). This illustrates that knowledge held by employees has a significant influence on improving employee performance.

\section{Effect of Skill Influence (X2) on employee work effectiveness (Y)}

The coefficient test result indicates that the T-count $\mathrm{X} 2$ value is 4.677 whereas the significance value is $>(=0.05(0.000$ $>0.05$ ) which means a partial skill (X2) variable affects positive and significant impact on employee work effectiveness (Y). This illustrates that technical skills such as the ability to apply computer have a significant influence on the effectiveness of employees ' work.

\section{Attitude influence (X3) to employee work effectiveness (Y)}

The coefficient test result shows the T-count X3 value of 0.886 whereas the T-table on the $0.005 \%$ trust level is 2.013 or $\mathrm{T}$-count $<\mathrm{t}$-table, this means the $\mathrm{X} 3$ variable does not significantly affect the employee's performance $(\mathrm{Y})$, in the sense that attitude variables do not have a significant influence on employee performance improvement.

Based on a partial test conducted on variables included in the analysis model it appears that the three research variables that are the knowledge variable (X1), Skill (X2), and attitude (X3) that simultaneously (together) have Influence and significance to the effectiveness of personnel work at the Office of the District Financial management of Bulukumba District. Similarly, if viewed partially it is known that the three variables are positive and significant.

\subsection{The Results of the Study}

The results of the above analysis showed that the effectiveness of employees working at the Financial Management office of Bulukumba District, is simultaneously influenced by the variables of knowledge, skills and attitudes. The most influential free variable is the knowledge variable it is in line with the assumption that in order to improve the ability and prowess of an officer in the field of duty, then what needs to be done is to increase the knowledge in Doing every job

Work/performance effectiveness is an achievement generated by a process or way of acting in a function. Performance puts a process that is pleasing to human resources activities in conducting the assigned work, given that performance is an activity related to elements involved in a process to produce something (output)

. Performance can also be explained as a representation of the level of achievement of an activity/program/and to realize the objectives, objectives, mission, and vision of the Organization. Performance indicators are quantitative measures describing the achievement level of a given goal or goal, taking into account the input indicators, output, results (outcomes), benefits, and impact. 
The improvement of employee performance is closely related to the increased knowledge made by each employee is also supported by a leader who can take every decision so that the objectives that have been set can be achieved at a maximum, especially In terms of output. The increase in performance of human resources also impacts employees where they can increase their productivity so that they can improve their lives as a result of achieving those outcomes.

\section{The influence Of Knowledge on employee effectiveness}

Knowledge is a person's level of ability in delivering information, ideas, facts, thoughts and feelings, from one person to another. In organizational life, knowledge becomes something very important because knowledge can improve the quality of work from a wide range of different activities/tasks.

Knowledge is needed so that officers know their obligations and responsibilities, this means that employees know their position in the organization. So knowledge can create the alignment of every employee's behavior in the group, in order to achieve one goal.

\section{Skills influence on Employee effectiveness}

The skills in an organization become one of the key factors that determine the success of an organization in achieving the objectives set. Skills can increase the quantity and quality of tasks, functions and obligations of an employee. Therefore, the conscious effort to deepen the various skills of quality needs to be done continuously. This is due to the success of an organization depends heavily on skill. So it is natural to say that the skills of an employee in an organization play an important role in the organization's success.

The results showed that the skills were influential and significant to the employees ' performance of the District Management office of Bulukumba District. An employee must be able to use his or her technical skills to complete the job in achieving the organizational goals. The success of an employee relies heavily on his ability to use his skills in every job so that his duties and responsibilities can be guided optimally in achieving the organizational objectives.

\section{Attitudes towards the effectiveness of employees ' work}

Attitude is a pattern of the behavior of a person in carrying out his duties and responsibilities in accordance with the Organization rules. If the employee has a nature to support the achievement of the Organization, then automatically any task that is charged to it will be executed properly

The results showed that the attitude of an employee in the organization is influential and significant to the employee performance of the District Management office of Bulukumba District. An employee should be able to demonstrate a good attitude toward the organizational goals. The success of an employee relies heavily on his ability to respond to all duties, obligations and responsibilities of each job so that his duties and obligations can be taken to the fullest in achieving the organizational objectives.

Based on the descriptions mentioned above, the three (3) variables above affect the effectiveness of the work then concluded that the competency of human resources is influential towards the effectiveness of employee work, especially in place The office of Bulukumba District Financial Management department.

As a strategy for the development of human resources competence should be used as a tool of work behaviour of employees combined with organizational objectives. To improve the performance of officers must pay attention to various factors such as improving knowledge, quality skills and good attitude to create the effectiveness of employee work.

\section{CONCLUSION}

Based on the results of research and data analysis on the influence of human resources competence on the effectiveness of employees ' work, researchers give the conclusion that:

Based on the partial tests conducted on the variables included in the analysis model, there are three research Knowledge variable variables $\left(\mathrm{X}_{1}\right)$ of 0.453 , Skill $\left(\mathrm{X}_{2}\right)$ of 0.393 , and an $\left(\mathrm{X}_{3}\right)$ of 0.066 that simultaneously (together) have influence and significance to the effectiveness of employees ' work similarly if viewed partially It is known that there are two variables that affect positively and significantly while the attitude variables are positively influential but not significant. 
From the above description can be seen that knowledge, skills, attitudes affect the effectiveness of work then the conclusion is human resources competency affects the effectiveness of employees ' performance.

\section{REFERENCES}

[1] Dharma, Surya. 2001. Manajemen Kinerja. Edisi ketiga. Pustaka Pelajar: Yogyakarta.

[2] Hasibuan, S.P. Melayu. 2003. Manajemen Sumber Daya Manusia. PT. Bumi Aksara: Jakarta.

[3] Hasibuan, S. P. Melayu. 2007. Manajemen Sumber Daya Manusia. Edisi Revisi. Bumi Aksara: Jakarta.

[3] Hutapea, Parulian dan Nurianna Thoha. 2008. Kompetensi Plus. PT. Gramedia Pustaka Utama: Jakarta.

[4] Jerome, Paul J. 2001. Mengevaluasi Kinerja Karyawan. Penerbit PPM: Jakarta.

[5] Kellinger, Fred N. 2000. Azas-azas Penelitian Behavior. Gajah Mada University Press: Yogyakarta.

[6] Kuncoro, Mudrajad. 2003. Metode Riset Untuk Bisnis dan Ekonomi. Penerbit Erlangga: Jakarta.

[7] Kusdi. 2009. Teori Organisasi dan Administrasi. Salemba Humanika: Jakarta.

[8] Mei, Syafitri. 2010. Pengaruh Kompetensi Terhadap Efektivitas Kerja Pegawai Pada Pusat Penelitian Kelapa Sawit (PPKS) Marihat. Skripsi. F.E USU: Medan.

[9] Moeheriyono. 2009. Pengukuran Kinerja Berbasis Kompetensi. Penerbit Ghalai Indonesia: Bogor.

[10] Norma, Sulastri. 2010. Pengaruh Kompetensi Karyawan Terhadap Produktivitas Kerja Karyawan Pada PT. Jamsostek (persero). F.E USU: Medan.

[11] Rivai Veihzal, dan Fawzi Ahmad. 2005. Performance Appraisal. PT. Raja Grafindo Persada: Jakarta.

[12] Situmorang, Syafrizal Helmi, Iskandar Muda, Doli M. Ja'far Dalimunthe, Fadli Fauzie Syarief. 2010. Analisis Data untuk Riset Manjemen dan Bisnis. USU Press: Medan

[13] Sugiyono. 2008. Metode Penelitian Bisnis. Cetakan Keduabelas, Alfabeta: Bandung.

[14] Sofiandi, Herman. 2008. Manajemen Sumber Daya Manusia. Penerbit Graha : Jakarta.

[15] Tangkilisan, Hessel Nogi S. 2005. Manajemen Publik. Gramedia Widiasarana Indonesia: Jakarta.

[16] Umar, Husein. 2008. Metode Penelitian Untuk Skripsi dan Tesis Bisnis. PT. Raja Grafindo Persada: Jakarta.

[17] Walpole, Ronal E. 2001. Pengantar Statistika. Edisi ketiga. Penerbit PT. Gramedia Pustaka Utama: Jakarta.

[18] Wiabisono, Dermawan. 2006. Manajemen kinerja. Penerbit Erlangga: Jakarta.

Wibowo. 2007. Manajemen Kinerja. PT. Raja

[19] Grafindo Parsada: Jakarta 